European journal of American studies

Special Issue: Envisioning Justice: Mediating the Question of Rights in American Visual Culture

\title{
"Rise like two angels in the night:" Sexualized Violence against Queers in American Film
}

Ralph J. Poole

\section{(2) OpenEdition}

\section{Journals}

Electronic version

URL: https://journals.openedition.org/ejas/14078

DOI: $10.4000 /$ ejas. 14078

ISSN: 1991-9336

Publisher

European Association for American Studies

Electronic reference

Ralph J. Poole, "'Rise like two angels in the night:" Sexualized Violence against Queers in American Film", European journal of American studies [Online], 13-4 | 2018, Online since 07 March 2019, connection on 08 July 2021. URL: http://journals.openedition.org/ejas/14078 ; DOI: https://doi.org/ 10.4000/ejas. 14078

This text was automatically generated on 8 July 2021.

Creative Commons License 


\title{
"Rise like two angels in the night:" Sexualized Violence against Queers in American Film
}

\author{
Ralph J. Poole
}

\section{Hollywood's Struggle with Queerness}

1 When revisiting the ways in which LGBTIQ* characters have been represented in American films throughout history, one comes to various conclusions, some of which strikingly contradict others. While queers-as I will refer to LGBTIQ* persons unless I want to specify a particular group such as lesbians or transgender persons-can be spotted even in earliest film productions, granting them leading roles in substantial numbers of films is a recent phenomenon. And whereas mainstream Hollywood films have featured the rare queer lead, it has been up to the independent and art house cinemas to produce a greater variety of characters with multifaceted screen lives. A case in point regarding the development of mainstream cinema is Vito Russo's The Celluloid Closet, which traces queers in film even back to the late $19^{\text {th }}$ century. Originally published in 1981, Russo in his afterword for the revised edition of 1987 points out a crucial marker of distinction: "Mainstream films about homosexuality are not for gays," he claims. "They address themselves exclusively to the majority. How should 'we' (society) react to 'them' (me)?" (325). Mainstream films therefore are made to entertain the broadest possible audience. In contrast to niche-oriented art house films, big Hollywood productions aim for profit, and this has consequences when it comes to including and depicting queer characters and plots. Russo refers to his own experience as a gay spectator lacking models for identification, emulation, and empathy. Instead, for him and presumably many like-minded, queers for much of mainstream Hollywood's history have been depicted as "Other"-despicable, pitiable, laughable. It is important to note that in the time between Russo's first and later revised editions, the AIDS crisis had taken hold, and with that negative images particularly of gay men gained renewed currency, which did not convince Russo of Hollywood's progressive 
politics with regards to queerness but rather only reconfirmed his initial outrage, as he states at the very end of his study: "The history of the portrayal of lesbians and gay men in mainstream cinema is politically indefensible and aesthetically revolting. ... Gays have always been visible. It's how they have been visible that has remained offensive for almost a century" (325).

2 Twenty years after Russo's landmark study on the homophobic history of Hollywood, Joe Wlodarz in an essay, aptly titled for the purpose of my paper "Rape Fantasies: Hollywood and Homophobia," affirms Russo's earlier claim that there is no dearth in queer images in Hollywood cinema as such, and similar to the many examples showcased by Russo, Wlodarz also highlights that what is missing in these instances are sex-positive filmic depictions. Instead, taking films as an indicator of a cultural climate he argues that "the intensity of the gay sex phobia in Hollywood speaks to (but doesn't limit homophobia to) the overdetermined significance of gay sex in dominant society" (68). One of the few modes of showing queer sex on-screen has been within the context of violence. Referring to a group of films that depict male rape and which he refers to as the "children of Deliverance"-John Boorman's 1972 film infamous for one of the most explicit on-screen depictions of a man being anally raped ${ }^{1}$-Wlodarz is intrigued how "male rape becomes symbolically coded as homosexuality" (68). ${ }^{2}$ None of those films are marketed as queer films nor are they about queers or rather more specifically gay men in any of those instances per se. And yet-or perhaps precisely because of the ostentatious marginality of the queer characters-"their presence haunts these scenarios in ways that blatantly reveal both straight male anxieties and psychic fantasies about anal sex between men" (Wlodarz 68). The conflation performed in these films of depicting sex between men (as an act of anal sex) and male rape (as the only way to represent such an act) is telling in how it relies on one of the strongest tropes of representing queerness in film: If queer sex is depicted at all, it most likely is done so within the context of violence. Wlodarz's valid argument, however, needs to be expanded to admit a critique of films not only showing sex between men, but examples of violent sexual acts that include other members of the LGBTIQ* community as well. Furthermore, we also need to look at films which no longer homophobically correlate queerness, sexuality, and violence without critically assessing this conflation and offering alternative viewpoints, but which self-reflexively engage in both the history of the stereotypical cinematic othering of queerness and ongoing revaluations of queer lives, including experiences of abuse, shaming, and other forms of violence in sexualized contexts.

3 Taking closer looks at pivotal moments of such representations of queerness in select American films, in this paper I address ways both mainstream Hollywood films and independent cinema have dealt with representing sexualized violence against queer (LGBTIQ*) people. Research on such depictions of violence remains scant and tends to focus on a few highly visible and publicly debated examples. I want to highlight crucial arguments surrounding some of those much-debated films such as Cruising and Boys Don't Cry, and then discuss lesser known but noteworthy examples such as Hedwig and the Angry Inch, The Skinny, Vacationland and Mysterious Skin, films largely arising out of the independent film movement known as New Queer Cinema. My claim is that all of those films, but especially the last mentioned, are not only far from shying away from markedly addressing the issue of sexualized violence, but that these representations contribute to a broader understanding of the complex dynamics of such acts, the 
possible traumatic effects they may cause, and ways to deal with perceived physical and emotional wounds. I want to ask if and in what ways these films continue to propagandize the conflation of sex, violence, and queerness, and whether they opt to work with, against, or beyond common stereotypes. The films in my view are not necessarily meant to mirror real life experiences of sexual trauma or to function as therapeutic templates for victims to emulate. But I do concur with critics such as Russo and Wlodarz that films correlate with the culture in which they are created. It is my aim, therefore, to discuss the aesthetic means employed in these films to depict sexualized violence against queers and to ask in what ways the films may be meant to engage the viewer, be it to draw him or her into the evolving narrative, for example, or perhaps to deliberately disengage the viewer from feeling empathy, pity, or shame. Probing narrative and aesthetic possibilities that the films may offer, my readings take part in a revisionist effort undertaken by queer scholars to include products of popular culture such as feature films in a broader discussion that envisions justice for queer victims of sexualized violence.

\section{Cruising: Moral Ambiguity within a Failing Justice System}

4 I first want to go back to the pre-AIDS era and take another look at a mainstream film that has garnered tremendous public attention, especially when it came out. It caused an uproar from the queer community at the time, and it remains provoking today: William Friedkin's 1980 film Cruising. Al Pacino plays New York cop Steve Burns, who in hopes for a speedy promotion goes undercover to investigate a series of murders in the gay community. Steve is set up as bait, since his looks resemble those of the murdered victims, and after initial drawbacks he gradually blends in and even befriends his gay neighbor, the gentle writer Ted. Eventually, he detects the killer, a schizophrenic fanatic with a father-complex, hunts him down, and seriously hurts him in a somewhat weak claim of self-defense. He also has a fit of violence against the jealous partner of Ted, who in turn is found dead soon after. The film's ending is open to speculation: while Steve has become estranged from his girlfriend during his investigation, he returns back home to her, and it remains unclear who murdered Ted. There are many instances where Steve seems to be "infected" by a milieu unbeknownst to him, and the film's title increasingly becomes ambiguous with Steve moving from "cruising" as detective activity to "cruising" as sexual prowling. To keep his cover, Steve even gets taken into custody and abused by the police as a seemingly gay man engaging in risky S\&M practices.

The film addresses sexual violence perpetrated against-mostly but not only-gay men. The crucial question then and now remains, whether the film's ideological thrust concurs with condemning the life-style of the queer subculture. Put bluntly: Is the film suggesting there is justification in killing off sexually promiscuous queers? Audiences and critics have never come to an agreement concerning an evaluation of the film's ultimate morals. Early critics as notable as Vito Russo and Simon Watney have teared the film apart for its rampant homophobia (see Russo 236-238, 259-263; Watney). Today, younger critics find Steve's character more intriguing, seeing him less as an incompetent detective than as bait for a heterosexual audience to gain insight into an otherwise unknown scene (Davidson 25). Such an approach locates Cruising within the 
film's by now historic setting during the hedonistic post-Stonewall and pre-AIDS era wherein the queer community celebrates its rights and sexual liberation. Partaking of this renaissance of interest in the film and its era is James Franco's and Travis Mathews's "documentary" Interior. Leather Bar (2013), which follows up on the supposedly missing forty minutes of footage that was cut (and lost according to United Artists) to prevent the film from getting an X-rating at the time of its release. Rumors have it-unproven as they are-that those scenes were above all cut because they showed an even greater interest and indeed participation of Pacino as Steve in gay sex.

For many critics-again Russo and Watney stand in for many more-Cruising has served as a prime example of the long-standing tradition in mainstream cinema of depicting queerness (if at all and especially in the genre of crime drama) as equating to death or murder. Contrary to such an overall assessment, a careful look at single scenes reveals that even one of the first already features unjust violence against transgender persons. Two police officers pick up two transsexuals hustling, and in their squad car they force the prostitutes to perform oral sex on them. This abuse of state power can be seen in other scenes as well, especially when suspects-including Steve-are severely beaten. The audience's sympathies in such scenes can be taken to be on the side of the violated victims since the police force is shown to be brutal and unnecessary. What is more, these police assaults are presented as sexualized violence, because they are accompanied by verbal degradation and/or sexual abuse. Other scenes have comic overtones, such as the one where Steve enters a gay bar all dressed-up in gay leather paraphernalia only to find that the fetish motto for the evening is "uniform." Thus, the irony is that he presumably is the only real cop dressed in leather amidst a crowd dressed in police outfits. While this is one of the scenes that shows Steve's still inadequate assimilation process, marking his increasing sexual insecurity, it also points to the contrasting analogy of police officers and gay men that the film sets up in general. As Gary Morris suggests: "Cruising points the finger for a violent, decadent society far past the gyrating leather queens, who come off more as fun-loving party-boys than sinister sexual psychopaths" (n.pag.). The rough sex in gay bars takes place with mutual consent, the violence performed by representatives of state power directed against queers does not.

7 Looking back, Benshoff and Griffin agree that "[d]espite the era's facile debates over whether or not Cruising was a positive or negative development in the representation of gay men, it has proved to be an enduring queer film that explores the borders (however murkily or irresponsibly) between male homosexual desire, 'straight' homosocial bonding, and violence" (183). By inserting a morally ambiguous hero (legacy of the hard-boiled crime genre) into a sexually charged underworld unknown to both the hero and the presumed mainstream audience, the borders of law and order become blurred. This scenario has led many critics to lament the genre's logic, which calls for searching and finding the perpetrator within this queer underworld in a manner that Kathryn Montgomery has outlined more generally as the "fundamental goal of garnering the largest possible audience [necessitating that] the story focus upon the heterosexual male lead character and his reactions to the gay characters rather than upon the homosexual characters themselves" (56). And yet, while Steve's admittance that "what I'm doing is affecting me" is a realization of this claim, it also points to a more complex reading than that since contrary to Montgomery's further claim that such a film must "avoid any overt display of affection which might be offensive to certain segments of the audience" (56), Steve's immersion into the gay scene in fact 
includes an emotional attachment to his gay neighbor as well as repeated sexual encounters with men in gay bars.

8 In reevaluating Cruising and the way that the film blurs the distinctions between perpetrators and victims thus shedding a dubious light on the criminal justice system, the traditional focus of classical narrative Hollywood films in regards to heterosexual romance gets debunked as well. As Robin Wood has shown for the genre of the horror film, the monster usually is constructed as sexually deviant thus serving as disturbing force against the romance plot (quoted in Benshoff 63). The same often is the case in crime dramas where the eruption of queer sexuality is felt as alien and troubling and linked to the "monstrous" killer. Steve's character, however, destabilizes this line of thinking since his queer "infection" is not temporary and strictly related to his investigation, but lingers and also affects his heterosexual relationship. Instead of getting rid of his queer undercover gear, he keeps it and even lets his girlfriend put it on, who thereby participates in this fetishizedly sexualized performance (see Wilson 107; Davidson 31, 43). This scene at the film's ending has an uncanny effect, because neither do we know whether Steve has indeed committed a murder (and has gotten away with it) nor can we be certain that Steve's girlfriend is as naïve and unknowing as she may seem. As such, this is an utterly queer moment that has emerged from its origin in the gay subculture and has drifted to the prime site of heteronormativity: the home of the heterosexual couple. With such a transition, the established, yet unjust equation of queer and monstrous has shifted as well and casts a sardonic shadow over the heterosexual romance otherwise invariably idealized in Hollywood cinema.

9 Cruising may remain a problematic film (not only) from a queer perspective, but the film certainly addresses a still rampant taboo in cinematic representations as well as in academic research on such films: sexual violence against males-homo- and heterosexual. To be sure, there have been instances of male rape scenarios in American film history. Johnny Holiday (Willis Goldbeck, 1949, re-released in 1955 as Boy's Prison) is an astounding early example where a boy gets gang-raped by other boys in the lockerroom of a reform school. Although the scene is shot from outside the shower room, the implication is obvious when one boy after another enters the shower and the boy finally emerges bleeding. While the backdrop of the reform school is meant to suggest that "bad boys" are being led back to the path of moral behavior, the rape scene attests to the contrary: The system of justice collapses in view of boys being further corrupted and performing deeds of injustice instead of being reformed. ${ }^{3}$

The failure of the justice system is also central to a film that has caused stirs similar to the ones Cruising triggered a decade earlier: Paul Verhoeven's Basic Instinct of 1992. The film features detective Nick Curran (Michael Douglas) falling for a murder suspect Catherine Tramell (Sharon Stone), and it has been heavily criticized for its depiction of (potentially) sadistic, homicidal bisexual/lesbian characters and for killing off two of these women seemingly "in the line of duty." While Catherine remains unpunished in the end, her former lover Beth (Jeanne Tripplehorn) is date-raped and finally shot by Nick, and her current lover Roxy (Leilani Sarelle), rather stereotypically depicted as a mannish-butch lesbian, also dies in the course of a "man-to-man" fight with Rick over who is entitled to make a claim on Catherine. The film's critical reception has tended to focus on the violence emanating from the lesbian and bisexual women, largely ignoring the violence they are subjected to by a representative of the justice system (Holmlund 34). Yet, a few critics with a queer reading of the film have argued that contrary to the 
usual (pornographic) trajectory of man-on-woman violence, this film allows a female audience to indulge in other-queer-kinds of fantasies that do not center on Michael Douglas as sex symbol. Instead, as Miranda Sherwin suggests, "lesbian desire lies at the heart of the murder mystery, and heterosexuality is merely a mask" (176). Like in the case of Cruising, queer scholarship has revaluated many films that have been dismissed due to their being subject to severe criticism-and I am not saying that in many ways this critique was not necessary and justifiable. What may be lost when focusing (only) on the conflation of sex, violence, and queerness that these films unquestionably purport, is the enjoyable thrill many of those films have also sparked for innumerous viewers, the lesbian vampire genre from Dracula's Daughter (Lambert Hillyer, 1936) to The Hunger (Tony Scott, 1983) featuring prominently among such queer audience favorites (see Weiss, Vampires 84-108). ${ }^{5}$ While such pleasure certainly was not always intended by the filmmakers, a wave of independent queer films since the 1990s has outrightly addressed conventionalized viewing habits and expectations. Many films of this wave, coined "New Queer Cinema," are meant to shock and delight, to criticize injustices and to dare showing hitherto unseen spectacles of celebrated queerness. Key examples, which include depicting the failures of the justice system to adequately deal with queer matters, are Swoon (1992) and Boys Don't Cry (1999), both of which in different ways engage in a dialogue with mainstream Hollywood cinema.

\section{Boys Don't Cry: The Unsustainability of the Transgender Gaze}

11 While many Hollywood productions continue to capitalize on long-standing stereotypes relating queer (repressed) sexuality to (acted-out) violence, independent filmmakers have gained prominence and a growing public recognition by turning such stereotypes against their assumed validity. In what has become known as "New Queer Cinema," many directors associated with this wave of queer filmmaking since the 1990s have engaged in the precarious aesthetics of representing sexual violence as a counterdiscourse to hegemonic heteronormativity. Tom Kalin's Swoon (1992) is a prime example of what Jude Davies and Carol R. Smith have described as emphatically depicting politically incorrect homicidal stereotypes (128-130). After Hitchcock's Rope (1948) and Compulsion (Richard Fleischer, 1959), Swoon is the third filmic interpretation of the notorious case of the 1920s child-murderers Leopold (Craig Chester) and Loeb (Daniel Schlachet). In resisting to produce purely positive images of queer and mainstream realist filmic conventions, Kalin aims at reconstructing alternative histories of queer identity, both by showing homoerotic images-and thus for the first time explicitly depicting the sexual relationship of Leopold and Loeb-and by highlighting-especially through an exaggerated non-realist visual manner-the unjustifiably ostracizing mechanisms of the legal, medical, sexual, and ethnic discourses of mainstream society. B. Ruby Rich states that "it's the history of discourses that is under Kalin's microscope, as he demonstrates how easily mainstream society of the 1920s could unite discrete communities of outsiders (Jews, queers, blacks, murderers) into a commonality of perversion" (28). The film in various ways engages with Hollywood and its oftentimes toxically charged representation of masculinity, queer and otherwise. Critics have noted Kalin's clandestine homage of Swoon to its predecessors Rope and Compulsion. And although the film is highly self-reflexive and 
constantly points to its own artificiality, forcing the audience to reevaluate images of (closeted) queer identity that stem from films such as Rope and Compulsion, Kalin's film has also been criticized for neglecting to call into question the naturalization of maleness (whether straight or gay) and its relation to idealizing and sexualizing violence: "In fact, this queer cinema has more in common with the current crop of male violence films ... than it does with any feminist cinema. Like Tarantino ... Kalin [is also the son] of Scorsese, whose films define and critique masculinity through violence but also make Robert De Niro a homoerotic object of desire" (Taubin 37). And yet, Rich includes Swoon in her original canon of New Queer Cinema, and she links this film to Basic Instinct of the same year, arguing that Kalin "struggled to reconcile his support for the queer community's disruption of Basic Instinct's shoot last spring with his film Swoon's choice of queer murderers as subjects" (17).

In contrast to Swoon, enjoying award-winning success mostly at independent film festivals only, another film has been perceived as paradigmatic in catching changing attitudes within traditionally gendered systems and has been hailed at the most prestigious and widely broadcast ceremonies of the American film industry such as the Academy Awards and the Golden Globe: Boys Don't Cry. Arguably, Kimberley Peirce's biopic or docudrama about Brandon Teena's life can be called seismic in the sense that it captures the frailty and collapse of a heteronormatively structured social environment. As such the film functions as a seismograph for social change since it signals a moment of crisis within a gendered system and points towards possible transformations of such systems (Stephan 13). While the dearth of research on the representations of sexualized violence against gays and lesbians in film has finally given way to an increasing scholarly attention, there is still less research on cinematic transgender characters being victims of rape, and clearly Boys Don't Cry serves "as an illustration of the extreme violence experienced by some transgender people" (Davies and Hudson 239). But like other films discussed earlier, this film, too, has experienced a history of shifting perceptions of its own that reflects on the complexity of habitualized viewing experiences all of us are subject to.

Boys Don't Cry can be seen as crossover film from independent to mainstream cinema, since it "became a critical and commercial hit, propelling issues of transgender identities and homophobic violence into mainstream culture" (Gieni 1). Especially with Hilary Swank's Academy Award-winning performance as Brandon, the film signifies a distinct moment for queering Hollywood, not least because her acting "undoubtedly helped to spread understanding about transgendered people to middle America" (Benshoff and Griffin 281). The film introduces Brandon as young pre-op transsexual man, who tries to be "invisible" through his male clothes, behavior, and desire. Brandon plays the "tough guy," drinks a lot, fights a lot, takes part in male bonding rituals, and hits on women. He does not shy away from getting beaten, he just wants to "belong." However, the everyday violence he encounters and participates in starts to bother him, and he decides to get away from his familiar environment and embarks on an adventure journey, which brings him to Falls City. There he befriends John (Peter Sarsgaard), Tom (Brendan Sexton III), and Lana (Chloë Sevigny), with whom he finds a substitute family. Even though the guys jokingly call him "little man" and "little dude," this new social atmosphere makes him feel supported as an equal member, and he even feels secure enough in his manhood to start a romance with Lana. At this point the positive story arc is interrupted and returns to the initial threats of violence, which 
now start to increase leading to the film's ultimate climax: Tom and John come to realize Brandon's transness and in four consecutive scenes, Brandon becomes subjected to acts of brutal sexualized violence.

In the first of these scenes, Tom and John rip off Brandon's clothes, and forcefully expose his female genitalia in front of Lana. This symbolic rape and castration through derisive male gazes on the naked female body is followed shortly after by a scene of actual rape by the two men. Besides its very real denotation as rape, the act can also be understood as yet another symbolic castration since again the female sex-the vaginagets reclaimed as "legitimate" site of intercourse (cf. Gieni 12-14). Brandon files charges, and the interrogation at the sheriff's office is a third scene of sexualized violence. Through the sheriff's skeptical questions Brandon not only has to relive his trauma but experiences another instance of symbolic rape/castration reinforced by the sheriff's ensuing deliberate inaction to press criminal charges against Tom and John (cf. Eileraas). The spiral of violence finally culminates in Brandon's utter defenselessness and eventual murder being both shot and stabbed by his rapists.

Boys Don't Cry has been discussed as belonging to the New Queer Cinema, arguably an ever-expanding movie canon that originally encompassed a small group of films appearing at the same time at festivals in the early 1990s such as Kalin's aforementioned Swoon. Rich observed this trend at the time and coined the term "New Queer Cinema" to bundle together these prize-winning films arguing that what unites them is a common aesthetics and politics based on an experimental postmodern visual style, and shocking plots with excessive violence announcing a radical renunciation of traditional moral values. The films also in more or less overt ways refer to the background of AIDS and the politically repressive Reagan era with queer people being especially targeted as scapegoats and becoming victims of social injustices. "Queer" arose as a newly reclaimed concept of identity, a marker to fight such rampant injustices, first through social activism related to the AIDS pandemic and the lack of support by politicians and the media but soon as aesthetic reaction of anger against the conservative, heteronormative social climate. Accordingly, the New Queer Cinema was born of dire political circumstances and took up the challenge to creatively counter these injustices. "Outrage and opportunity merged into a historic artistic response to insufferable political repression: that simple, yes, and that complex," recounts Rich and continues that "the New Queer Cinema created a space of reflection, nourishment, and renewed engagement. ... An invention. A brand. A niche market" (Rich xvi, xix). In her introduction to a revisiting of the New Queer Cinema, Michele Aaron claims Boys Don't Cry as central example for the changes in audience identification being spurred on by this cinematic movement:

No longer does popular culture have to seem to render queer configurations safethrough, for example, humour, homophobia (or other memos of heterosexuality) and, especially, closure. In the remarkably popular Boys Don't Cry, the queerness of Brandon's girlfriend (and the spectator by implication) is indulged rather than repressed, as time and time again the narrative constructs her complicity in Brandon's disguise as a man. Popular culture no longer has to disavow queerness, but, of course, it still does .... And, after all, such things underline mainstream entertainment. What is crucial to remember is that disavowal is a defensive mechanism; queerness must only appear to be quelled. (New Queer Cinema 11)

It is here, at this intersection, where some hermeneutic problems of the film arise. In singling out Lana-not Brandon-as the viewers' object of possibly queer identification as Aaron's comments support, does the film then only appear to disavow queerness, or 
does it succumb to the enduring homophobic powers of mainstream culture? Aaron opts for a positive solution arguing that within mainstream audiences a "new queer spectator" has emerged who is willing to suspend the usual defensive mechanisms: "New Queer Cinema's impact upon mainstream cinema can be measured not only in terms of the influx of lesbian and gay directors, or of 'defiant' characters or queer themes, but in terms of the audience's consensual flirtation with gender and sexual ambiguity within some of the most popular texts" ("The New Queer Spectator" 187). The gendered and sexual ambiguity thus not only relates to Brandon, but also to Tom and John, whose pubescent looks suggest men-in-the-making and whose intimate homosociality-their intoxicated orgiastic embraces after raping Brandon, for example -give cause for irritation (cf. Eileraas). Strict categories are avoided or at least called into question, and accordingly a one-dimensional victim-perpetrator-model seems cancelled with the aggressors being not only monsters and Brandon not only a martyr (cf. Aaron, "The New Queer Spectator" 192). In this sense, Boys Don't Cry is a paradigmatic example for a crossover success of independent/queer cinema, and while heterocentric and potentially homophobic imperatives still reign in mainstream cinema, with films such as Boys Don't Cry there has come forth a broader spectrum of queer moments resisting categorical unambiguousness of gender and sex and thus defying a clear-cut representation of the dynamics of sexualized violence.

In a provocative rereading of Boys Don't Cry, however, Judith Halberstam ultimately argues against the film's queer progressiveness by referring to the final shift from trans to lesbian in Brandon's representation which Halberstam calls catastrophic. She grants the film fleeting instants of a transgender gaze through which the viewer succumbs to moments of identification by taking on Brandon's self-identifying perspective of himself. In such moments, we follow the trans person's own gaze thus "forcing spectators to adopt, if only for a short time, Brandon's gaze" (294). Such scenes play on the traditional trajectory of male and female gazes and momentarily undercut the ideological mechanisms of heteronormativity.

To be sure, Brandon's initial self-assertion of transness in the early parts of the film undergoes several shifts, starting with the one to Lana's empowered female gaze in their first sex scene, and ending in their final intimate encounter where the potentiality for subversion resonating in prior scenes is reversed by collapsing the transgender gaze into a romanticized lesbian gaze. In the initial and explicit sex scene, in which Brandon uses a dildo and Lana willingly relinquishes a probing look at Brandon's naked body, Lana's unwillingness to participate in the men's violating gaze is both empowering in its own right and supports the claim to Brandon's authentic masculinity. In contrast, the later more romantically depicted love scene shows Lana's now inquisitive gaze on his female body. Not only does that shift disempower Lana's initial readiness to accept Brandon's trans identity. Highlighting Brandon's physical femaleness through Lana's gaze turns this into a woman-on-woman scene, a romantically clichéd lesbian coupling, thus relinquishing the transgender agenda altogether. This scene is highly problematic, according to Halberstam, because it occurs after the rape and thus fatally suggests a certain logic that links the violent scene to the ensuing romantic one. In both sequences Brandon is disrobed and reduced to her naked 'true' self as a woman, and while in the first of the scenes her naked female body is brutally violated by John and Tom, in the second Brandon "now interacts with Lana as if he were a woman" (Halberstam 297). The earlier graphic sex scene between Brandon and 
Lana was depicted as a suspension of expected gender roles, the later scene enacts a stabilization again "by a Hollywood-style dissolve as if to suggest that the couple are now making love as opposed to having sex" (Halberstam 297).

Apart from Boys Don't Cry, Halberstam's observations are essential in that they question the sustainability of any such transgender gaze for more than just "a short time" in a broader sense. This is especially relevant when looking into the visual politics of films related to the romance genre and asking "about the inevitability and dominance of both the male/female and the hetero/homo binary" (Halberstam 294). While a film's use of the transgender gaze may help to counter injustices by empowering the otherwise ostracized figure, recentering the focus away from the margins buttresses the representations of injustices against queers. These depictions continue to be sanctified by a visual culture that by and large remains heteronormatively and transphobically structured. ${ }^{6}$

\section{Racialized Comic Switchpoints in Hedwig and the Angry Inch and The Skinny}

Besides the loss of a genuine transgender perspective, Halberstam also comments on the neglect of race in Boys Don't Cry. The film erases the real-life story of Philip DeVine, a disabled African-American man who dated Lana's sister and-like Brandon-is killed. Refusing to pick up on the "hard facts of racial hatred and transphobia" (Halberstam 298) that were fatally linked in the actual Brandon Teena case, Peirce's fictionalization reduces the complexity of the factual case. Focusing solely on Brandon's fate, the film turns this murder into an act of homosexual panic "ignoring altogether the possibility of exposing the whiteness of the male gaze" (Halberstam 298) in both Brandon's and Philip's murder cases. A few-very few-films have been more sensitive to the link of trans/queer phobia and racism, if not always with unambiguously satisfying solutions to envisioning an on-screen justice for queers of color. The two films I want to discuss for raising awareness of the overwhelming cinematic taboo of sexualized violence against queers of color operate in different genres (musical, romantic comedy) and with very different means of representing violence within a sexual context. Both films, however, employ the strategy of switchpoints, in one case to counterpoint white and black bottoms, and in the other to shift from a scene of laughter to one of violence. Both, Hedwig and the Angry Inch (2001) and The Skinny (2012), are daring in defying prescribed gendered formulas within generic conventions.

21 A striking scene in the musical film by John Cameron Mitchell, Hedwig and the Angry Inch, features the racial(ized) gaze on a body that in the course of the narrative will turn into a transgendered body. The film follows the career of the East German transgender musician Hedwig (John Cameron Mitchell) from post-war Berlin to the U.S., and the scene at stake is shown as flashback to the past where Hedwig, still as the young boy Hansel, lies naked and bottom-up taking a sunbath amidst a setting of rubble near the Berlin Wall. There he meets an older black American army sergeant (Maurice Dean Wint), who offers Hansel marriage and escape under one condition: a sex-change. The surgery is botched, however, and leaves Hedwig with an "angry inch," marking her gender inconclusiveness. This scenario of transition is based on a structure of power and violence: an economic-sexual-medical deal with underlying notions of prostitution, pederasty, miscegenation, and castration. Tragic irony has it that Hedwig's transition 
to woman and to America coincides with the fall of the Berlin Wall making both actions superfluous. Once in the U.S. the relationship ends, and Hedwig is on her own. Alas, why does the film about a transgender performer need a black Sugar Daddy?

For the audience, Hedwig's identity becomes embroiled with that of the black Sugar Daddy, and through this entanglement various historical layers coincide. Some of these are linked to histories of violence and shaming so different from one another that the viewer is startled into wonderment: "We only know for sure that the film puts the sign of a black man (differently queer from the boy) at the origin of the 'angry inch' - the start of a surprisingly tender debasement, which it is the viewer's troubled task to comprehend" (Stockton 5). Kathryn Bond Stockton argues that the black man's momentary passage through the film's narrative "works as a fascinating switchpoint ... the point at which one sign's rich accumulations-those surrounding 'American black'-lend themselves to another-'East German queer"' (4). Stockton uses this particular scene-the black Sugar Daddy gazing at young Hansel's white bottom-as initial example in her book on Beautiful Bottom, Beautiful Shame: Where "Black" Meets "Queer" to introduce the concept of switchpoints as points of connection between two separate connotative fields where something from one field "switches" to the other with decisive consequences. Like a railroad switch used to transfer a train from one track to another, switches in a general sense mark sudden and perhaps unexpected transferences, and thus expanding and shifting signification.

Stockton does not discuss the irritation arising from the switchpoint in Hedwig and the Angry Inch in terms of genre, but certainly this is part of the "trouble." The narrative could have been cast in the gloomy atmosphere of melodrama, but it was the genre of musical that was chosen instead. While Hedwig and the Angry Inch is not overflowing with comedy, the film nevertheless relies on the conventions of the musical as popular entertainment and in this case especially camp transgender aesthetics. And yet it deals with repeated instances of sexualized violence starting with the black Sugar Daddy's gaze on Hansel's white bottom that challenges the metaphoric notion of the black bottom as signifying "the nadir of a hierarchy (a political position possibly abject) and as a sexual position: the one involving coercion and historical and present realities of conquest, enslavement, domination, cruelty, torture, and so on, the other involving sexualized or erotic consent/play which references the elements of the former" (Scott 28). Clearly, in Hedwig and the Angry Inch, these historically laden power relations are swapped: The black Sugar Daddy is (on) top in terms of social and sexual domination, Hansel, in turn, at the bottom in each of these aspects. Here, for a fleeting but crucial moment in the narrative, the historical relation between blackness and abjection that Darieck Scott theorizes in various literary contexts through the figure of black male rape materializes as a precarious and uncomfortable counterintuitive presence-a switchpoint turning the cards of the play.

Like Hedwig and the Angry Inch, a film imbued with humor as well as scenes of interracial sexualized violence that are precarious to navigate, The Skinny by Patrick-Ian Polk is a film using many comedic elements and including an unexpected scene of sexual violence. In contrast, however, this film features almost only black characters/actors. A group of young black former fellow-students reunite to participate in New York's gay pride festivities. Amongst them is Sebastian (Blake Young-Fountain) who, despite having spent time in Paris, is still a virgin, a fact that causes playful banter by one of the group: "You're a virgin? Still? .... Nine months in Paris, the most romantic city in 
the world! I just figured some Frenchman would have plucked that flower by now." Sebastian wants to take advantage of the weekend to be deflowered by Kyle (Anthony Burrell), the group's irresponsible but alluring stud. Part of the film's farcical humor includes an extended lesson in how to prepare for such an event with an anal cleansing ritual supervised by Joey (Jeffrey Bowyer-Chapman): "Just think of the rectum as like a poop-chamber, a waiting-room for the waterslide journey into our sewer system." The anal shower will prepare Sebastian "ready to get your hole royally plunged" by Kyle as far as the plan goes.

But Kyle, having no clue, is rather interested in other men, and while he plays around he loses track of Sebastian, who then gets the date rape drug GHB slipped in his drink and ends up with two guys raping him. These two rapists are characterized as promiscuous, masculine men highlighting the victimized Sebastian in contrast as "inexperienced, drugged, and effeminate" (Copeland 51). Accordingly, this scene can be linked to "down low" films such as Cover (Bill Duke, 2007) featuring "the paradigmatic 'down low' (DL) man" (Strongman 17), who typically is a lower-class black man who has sex with other (black or white) men without considering himself gay and who is marked by dangerous hypersexuality and intraracial homophobia. ${ }^{7}$ By relegating the two anonymous rapists to the sidelines of the narrative, The Skinny shifts the attention to the sex-positive attitudes of the group of friends. Also, the actual rape scene is not exploitatively shown in full length. We see Sebastian groggily being led out of the bar by the two strangers and the immediate shot afterwards shows his friends in the morning worrying about the still absent Sebastian, who then can be seen waking up in bed lying between the two still sleeping strangers. He realizes that he is naked and anally bleeding, and calls Magnus (Jussie Smollett) to pick him up. While waiting for his friend, who brings him to a gay health care center, Sebastian remembers bits and pieces of the preceding night. Although we know that clearly this is not what Sebastian had in mind for his 'first time,' we do not witness any overt violence or gritty realism in those flashbacks. The sex is shown in a non-threatening, erotic soft porn aesthetic instead. But the tests run at the health center prove that Sebastian indeed was under unwanted drug influence and also subjected to unsafe sex, which makes this sexual act a rape crime with potential health risk consequences besides the experienced trauma.

This moment of utter disillusionment, danger, and violence is shocking in a queer film that relies on a humorous approach to virginity and first sex. And although the ending is conciliatory, Sebastian's longing to have his "special gift ... my flower" romantically taken by a close friend that he adores is radically undermined by an act of sexual violence which leaves him scarred not least by having no memory and being exposed to a potential HIV infection. The film with its traumatic defloration scenario sits uncomfortably with the genre conventions of the romcom-queer or otherwise. Sebastian's prissiness and the anal cleansing lean towards the farce, a form of comedy that according to Andrew Stott "relies principally on physical humour, horse-play, and awkward social situations to generate laughter" (150). Referring to Mikhail Bakhtin's work on Rabelais and the concept of the carnivalesque and the grotesque, William Paul even argues that farcical, grotesque humor is a popular means of highlighting vulgar scenes, and the genitals are especially prone to such gross-out acts, which "make the audience laugh, make the audience scream, make it scream with laughter, make it laugh in terror, create a 'laff riot' or a 'screamfest' to stir up the pleasure of pandemonium" (65). Whereas films such as Another Gay Movie (Todd Stephens, 2006) celebrate this screamfest in the communal effort of a group of young gays trying to get 
deflowered which includes many scenes of playful over-the-top violence but never in a way that does injustice to the queer characters, in The Skinny this humor turns sour when confronted with a scene that is nowhere near funny but a vicious, unplayful, and unjustifiable instance of sexual assault, even though or perhaps precisely because it is drawn within the conventions of porn aesthetics. The scene therefore serves as a switchpoint through the transference of the physical site of incongruous laughter-the elaborately cleansed rectum-to one of unconsciously experienced violence-the rectum as a bleeding locus of rape-to that of potential death through possible infection, or, as Leo Bersani has famously argued in "Is the Rectum a Grave?," to a heightened focus on the opening into the (queer) male body that is culturally associated with inferiority, abjection, and disgust. To represent this bottom as a queer black one only heightens the unexpectedness of the switchpoint in this particular film.

The Skinny undermines the generic expectations of romantic comedies in numerous ways, not least for being outspokenly queer. Following the ensemble formula set up by romcoms such as Four Weddings and a Funeral (Mike Newell, 1994) or Love Actually (Richard Curtis, 2003), there is no single romantic couple but several protagonists struggling to find "the one." These ensemble films usually have some of the wished-for couples coming together in the end, while others split up and remain single or enter new relationships. The Skinny has only one relationship at the outstart, Magnus and his partner, and they seem to have split up at the end. And while two other group members -Joey and the lesbian Langston (Shanika Warren-Markland) - have erotic adventures, no lasting relationships are forged. Finally, Sebastian's love object Kyle turns out to be no substantial boyfriend material, and they part ways, amicably but permanently. Ultimately, the happy if somewhat mellow ending features no spectacular closing scene with the lead couple kissing amid a group of cheering witnesses and thus goes against the traditional heteronormative romcom principle that Debra Moddelmog has described as follows: "Repeated again and again, this union-as-spectacle scene shores up the genre's premise of heterosexuality and visually reminds us that the Hollywood film industry is still committed to the view that heterosexuality, and a particular kind of heterosexuality at that (monogamous, affluent, predominantly white), is the only acceptable choice for anyone looking for love" (163). The black queer ensemble cast, the refusal of monogamous coupling, and above all the inclusion of a very unromantic and un-comical plot twist with Sebastian's rape all help to create an alternative to such formulaic films, where "the one who has really never been kissed, at least in Hollywood romantic comedies, is the queer/gay subject, especially the queer/gay subject of color" (Moddelmog 163). The alternative, however, is an uncomfortable one, relying on the complex logic of switchpoints that lends itself to disidentifying viewing practices. Queer and straight, black and white audiences may have to readjust their expectations and take on the perspective of a queer black minority, an experience of disidentification that José Esteban Muñoz has described as being "meant to be descriptive of the survival strategies the minority subject practices in order to negotiate a phobic majoritarian public sphere that continuously elides or punishes the existence of subjects who do not conform to the phantasm of normative citizenship" (4). The Skinny is a rare instance of a progressive queer black cinema that productively problematizes the triple marginalization of black queer men "as black males, as gay males, and as traumatized males who may have internalized the wanton violations of civil rights" (Lemelle 147) and accordingly defies stereotypes that either feminize or hypersexualize black queer men. 


\section{Reparative Impulses in Vacationland and Mysterious Skin}

If, as Lynn Higgins suggests, "rape is a perfect crime for film" (306), it is because of the convergence of sex and violence making for an enthralling spectacle. Adding queerness to this intersection lessens nothing of its spectacular appeal. Besides films that include scenes of homophobic queer-bashing and rape with traumatic effects for its victims such as Amnesia: The James Brighton Enigma (Denis Langois, 2005) or in a more playfully surrealist mode Strapped (Joseph Graham, 2010), porn films are a major venue to capitalize on this convergence. Straight pornography, as John Stoltenberg argues, "is rife with gay-baiting and effemiphobia. ... The innuendo that a man is a 'fairy' or a 'faggot' is, in pornography, a kind of dare or a challenge to prove his cocksmanship" (72). In contrast, gay male porn has become an important component of asserting one's sexual identity as a gay man: "Because if you think the problem facing you is that your masculinity is in doubt because you're queer, then the promise of gay male pornography looks like forgiveness and redemption" (Stoltenberg 72). Queer Cinema has an intricate relation with pornography, and many films overtly address this connection. King Cobra (Justin Kelly, 2016), for instance, is a film about the porn industry, based on the actual early career of gay porn star Sean Lockhart aka Brent Corrigan (played by Garrett Clayton), and it depicts porn producers as neurotic, abusive, and exploitative. In an act of utter and bloody violence, one of these producers, Stephen (played by Christian Slater and modelled after Bryan Kocis), is stabbed by Harlow Cuadra (Keegan Allen), who together with Joe Kerekes (James Franco) teams up to eliminate Stephen from the porn industry. Joe and Harlow have been wooing Sean as a new star to boost their porn label, but Stephen has been refusing to release Sean from his contract.

The film's most obvious and overt violence, the murder of Stephen, is not an act of sexual violence, although the situation from which the murderous act emanates is sexualized: Harlow poses for Stephen, even seems to seduce the producer in a performance that suggests the reversal of the usual roles with the producer seducing a potential future actor during a "screen test" to ascertain his performance qualities. The real but hidden sexual violence lies somewhere else and has two sources. The first is Harlow's sexual abuse that he suffered early on as a boy and that seems to have triggered at least in part his bloody stabbing of Stephen, who for him represents an abusive father figure. Also, Harlow's relation to Joe, although depicted as love relationship, is overshadowed by Joe's domineering, jealous behavior that points to his serious psychological problems. Their relationship serves as mirror for the evolving but failing relation between Sean and Stephen. Whereas Sean comes across as the only mentally stable person of the four protagonists, he nevertheless is easy prey for Stephen due to the former's lack of experience. Sean is still a minor at the time when Stephen casts him in porn films, taking advantage of the boy's economic dependence. And this is the source of the second and most criticized instance of sexual violence in the film. Stephen is shown as a very efficient and successful producer who nevertheless is extremely self-conscious, fearing to lose his sexual attraction with increasing age, and who forces boys like Sean into sexual compliance while exploiting them financially. 

scenario in the films of Todd Verow, whose unapologetic aesthetics stems from the New Queer Cinema but has lately moved into the realm of reparative impulses. His early film Frisk (1995, based on the novel by Dennis Cooper) still is grossly violent and darkly humorous in detailing a boy's fascination with snuff porns and his resulting wish to see what an opened body looks like. As Joan Hawkins remarks, "Frisk forcefully calls into question what's considered low culture and what's considered 'art.' Incorporating images from S\&M porn magazines and adult videos, it raises the unsettling question of the roles which pornography and the media play in shaping an individual's psyche" (92). The film draws on the clash between the setting of nice upper-middle-class neighborhoods and the violent interests of the equally nice-looking college kids living there. Fiercely unsentimental, the film shocks the audience in its detached attitude towards sexualized violence, deliberately using "the visuals and thematic tropes of 'low' genres like horror and porn to make their point" (Hawkins 92), i.e., exploiting violence to provoke real sensations in the audience, which according to José Arroyo must necessarily fail due to censorship regulations. To really represent such murderous sexuality, "one that verges on sensual cannibalism ... it would have had to create sublime imagery that could simultaneously make viewers understand such murderous sexuality, but also evoke dread and disgust at the notion that their own desires might be complicit with the protagonist's" (Arroyo 41). Frisk, his first feature film, catapulted Verow into the elite of the New Queer Cinema while at the same time, as the director himself recalls, giving cause to outrage and disgrace reminiscent of reactions to Friedkin's Cruising 15 years earlier: "A riot broke out at our screening during the San Francisco Lesbian \& Gay Film Festival, the editor of The Advocate magazine said I should be shot, the writer of the book denounced the film and The New York Times declared the film the "ne plus ultra of queercore.' I had arrived in style" (392). Araki, who not only continued to create controversial films but also garnered substantial scholarly attention, Verow has not received as much response by academics although his films deserve such notice. This lack of academic interest is surprising not least since he is hailed by film critics as one of the most original voices of the movement, and his films are routinely selected at prestigious festivals. Amongst these films are Anonymous (2004), Vacationland (2006), and Between Something \& Nothing (2008), all of which are semi-autobiographical works addressing his "own past [and] own demons" (Verow 394). These films are very different in style, content, and ultimately politics from Frisk and from other early New Queer Cinema films, and yet, as Verow argues, "filmmakers must experiment. ... We must resist the traditional narrative structure. Resist closure and embrace ambiguity" to counter the "shiny happy films, a New Gay-sploitation Cinema" (394) that simply pleases the audience, a jab at those queer films that have lost the cutting edge of the original New Queer Cinema politics and aesthetics. In Vacationland, Verow plays with those queer "shiny happy films"starting with the title-only to debunk their superficial happiness and to unearth lingering traumas. He does so, however, with aesthetic means that are far removed from the ones he employed in his earlier Frisk.

Vacationland takes us to Bangor, Maine, Verow's hometown, to follow Joe's (Brad Hallowell) coming-of-age as artist and gay man. As a kid from the Capehouse projects, his chances to escape his poor lower-class background are slim, and his artistic

European journal of American studies, 13-4 | 2018 
ambitions and his being torn between secretly loving his best friend Andrew (Gregory J. Lucas), the football jock, and unenthusiastically dating the cheerleader star Mandy do not help improve his prospects. Everything changes when Joe starts to model for the old, disabled gay artist Victor (Charles Ard), with whom he soon enters a highly emotional, but sexless mentor-student relationship. Victor helps Joe pursue his dream of studying at the Rhode Island School of Design. The film has comedic scenes, for example when their two dissatisfied girlfriends encourage Joe and Andrew to have sex while they are watching, which develops into a secret sexual arrangement between the boys and the girls. But the reason for discussing the film in the context of sexual violence against queers is a dark secret that the audience only realizes in the latter part of the film when it comes to the surface and results in a revenge scenario. It turns out that Joe was raped at the age of ten by the boss he was working for, who does not even remember Joe when they meet again later, suggesting that Joe was one among many. Together with Andrew Joe takes revenge by striking him unconscious and dumping him at the beach with "FAG" in lipstick written on his forehead. Another of the boss' earlier victims, Tim (Michael John Dion), happens to find him there and presumably kills him in a boost of rage. The last image we see is Joe and Andrew sitting peacefully and kissing on the beautifully lit scenic waterfront with Joe's voice-over speaking of a brighter future:

You would think being around so many horrible things over and over again would make you want to hide away, afraid of the world. That you would want to escape, crawl in some protective shell, become hard, cynical, and emotionally dead. But actually, it had the opposite effect on me. In a strange way, it made me feel like anything was possible. You just got to be awake, aware of everything around you. When something horrible happens, be ready for it, expect it even. And when opportunity presents itself, take advantage of it, do not hesitate for one second. (Vacationland)

Although film critic Michael D. Klemm in an otherwise appreciative review feels that the "grim happenings of the final act" ("Bangor Buddies") weaken the film's overall appeal as guerilla art, I consider the traumatic childhood experience of sexual abuse compelling precisely because it both overshadows much of Joe's queer maturation and yet does not result in a stalled paranoid life-narrative but in a reparative impulse to love. I am taking my cue from Eve Kosofsky Sedgwick, who has suggested that to take on "a reparative position is to surrender the knowing, anxious paranoid determination that no horror ... shall ever come to the reader as new; to a reparatively positioned reader, it can seem realistic and necessary to experience surprise" (22). While surprises can be terrible or good, a reparatively positioned person utilizes hope as an energy to reorganize those experiences, because the person "has room to realize that the future may be different from the present [and that] it is also possible for her to entertain such profoundly painful, profoundly relieving, ethically crucial possibilities as that the past, in turn, could have happened differently from the way it actually did" (Sedgwick 22). Critics have taken up Sedgwick's notion of reparative reading to ascertain that such a stance arises from "the obvious fact that our world is damaged and dangerous" and develops into a "creative act of love, albeit one that is grounded in disillusion rather than infatuation" (Hanson 547). Instead of "repeat[ing] the bad news," according to Ellis Hanson there is an impulse to "build or rebuild some more sustaining relation to the objects in our world, including art and the criticism of art" (547). It is no coincidence, I believe, that Joe in Vacationland evolves to be an artist. Although giving in to the impulse to revenge, he nevertheless in the end embraces the gift of love to 
Andrew and looks ahead to studying art thus hopefully continuing to channel his early experiences of injustice into other than violent futures. Another film, which even more radically employs a reparative impulse in a narrative of surviving child abuse, is Mysterious Skin.

Gregg Araki, the Asian-American director of Mysterious Skin (2004), once was "the bad boy of the New Queer Cinema" (Rich 92). Films such as The Living End (1992), Totally $F^{* * *}$ ed Up (1993), The Doom Generation (1995), and Nowhere (1997) placed him right in the midst of that wave of films appearing around 1990, which were shocking in their euphoric scenes of violence and the radical lack of offering any mediation for a non-gay audience. Similar to Boys Don't Cry, Mysterious Skin, an American-Dutch co-production, has moved out of the niche of independent cinema, crossing over to mainstream success. It is a highly complex film about two boys who suffer sexual abuse by their baseball coach (Bill Sage) at the age of eight. Neil (played by Chase Ellison as the boy and by Joseph Gordon-Levitt as 18-year old Neil) and Brian (George Webster as young and Brady Corbet as older Brian) each deal with the "zombifying (or numbing) effects" (O'Connor 59) of their trauma in a different way. While Brian seeks amnesic escape in an asexual world of fear, in which he believes to have been abducted by aliens as cause for his trauma, Neil moves on to be a hypersexualized and cold-blooded hustler, who seemingly is willing to offer himself up for further sexual violence. The disjointed plot brings the two together towards the film's end after ten years, when they experience a moment of deep, even spiritual cleansing of the injustice they suffered from. Rich has called this film Araki's "biggest risk of his career" (95) precisely because the excessive violence of his former films has disappeared giving space for mystic dreamscapes of traumatic childhood. With Mysterious Skin, Araki has moved away from his earlier comedic-melodramatic camp films abounding with popular culture references towards an aesthetics that is both more compatible with mainstream tastes yet just as radical in the power of its message, because it is the violence that a character has to endure which empowers him to relate to another abused character but under radically new conditions beyond normalized romance.

The film starts out with an image of young Brian with his nose bleeding and his older voice-over saying "The summer I was eight years old, five hours disappeared from my life. Five hours. Lost. Gone without a trace." Brian's amnesia is initially radically juxtaposed to Neil's narrative, whose older voice confesses to projected images of his younger self at his first sighting of the coach: "Desire sledgehammered me. He looked like the lifeguards, cowboys and firemen I'd seen in the Playgirls that my mom kept stashed under her bed. Back then, I didn't know what to do with my feelings. They were like a gift I had to open in front of a crowd." The coach's seduction of Neil is accompanied by Neil's conflicting desires, the acceptance of his queerness, his evolving tough-guy attitude along with his hustling career until a particularly violent encounter with a client leaves him heavily injured and bleeding. At this point and towards the end of film, Neil and Brian finally meet again after ten years. Neil takes Brian to the house of the coach, who does not live there anymore. They enter anyhow, and Neil tells everything that happened the night he helped the coach to lure Brian into various sex acts. With flash-back images interspersing Neil's tale and signaling that Brian now too is remembering, the relived trauma causes Brian's nose to bleed again, as it did that night. The scene turns surreal with the bleeding Brian being held by the heavily bruised Neil while outside children sing "Silent Night. Holy Night. All is calm. All is 
bright." Neil's narrating voice takes over, his are the last spoken words of the film while the camera lifts and moves away from the couple, who become smaller and smaller and finally disappear altogether into a black screen:

And as we sat there listening to the carolers, I wanted to tell Brian it was over now and everything would be okay. But that was a lie, plus, I couldn't speak anyway. I wish there was some way for us to go back and undo the past. But there wasn't. There was nothing we could do. So I just stayed silent and trying to telepathically communicate how sorry I was about what had happened. And I thought of all the grief and sadness and fucked up suffering in the world, and it made me want to escape. I wished with all my heart we could just leave this world behind. Rise like two angels in the night, and magically ... disappear. (Mysterious Skin)

Andrew Asibong considers this closing scene as "among the most bewitching and emotionally devastating in contemporary American cinema" (193). The boys' return to the house of their childhood abuse offers a space of precarious redemption, heightened but also ironically undercut by Christmas carols. The promising lyrics of "Silent Night" clash with the depicted scene, indeed all is silent, but nothing is bright. There is no envisioning justice in the end, the film's hyperbolic last images and sounds preclude the possibility of such a satisfying closure, instead. There cannot ever be sufficient absolving from the injustice done to the boys, and yet there is a moment of epiphany symbolized by the Pietà-like image of Neil holding Brian. The shared memory brings forth a moment of intimacy, perforated however by flashbacks to the scene of abuse and visually heightened by the shared bleeding. Neil's bloody wounds from a violent customer and Brian's nose-bleeding as traumatic body-affect become conjoined: "Unthinkable kinship, in this film, emerges precisely from a shared abrasion of the soul and skin" (Asibong 191). Neil as narrator leads Brian - and us - much like a stagedirector through this fantastic scene, and through Neil the film addresses very disturbing questions, especially his encounters with the trainer as almost pornographic fantasies of his younger self. In this sense, the film offers important cultural commentaries on sex and violence in conjunction with queerness, precisely because of complicating the affective as well as identity-destroying potentiality of violent sexual acts against queers.

\section{Conclusion}

All films discussed here have made crucial decisions of how to represent such violence. While Cruising mostly hints at various acts of sexualized violence including an almostrape of the protagonist Steve, Boys Don't Cry graphically depicts Brandon's rape by his two "friends." Both, Hedwig and the Angry Inch and The Skinny couch the traumatic abuse in an overall comic narrative, the violent acts are never shown in a straightforward explicitness, and yet the effects are noticeable through the visual and narrative technique of contrasting switches (black/white, comic/violent). Vacationland has also refrained from actually showing the scene of sexual abuse; Verow's film relies on implying the emotional aftermath through the confessional tale of its victim, instead. Mysterious Skin diverges from the arguably more conventionalized formulas of either explicitly showing violence or implicitly hinting at its effects. In contrast, the film simultaneously tells the crime through the disembodied voice of one victim and shows flashes of this deed, representing the diverging experiences of both victims. This does not add up to a realist representation as in most of the films I discussed here, but lends 
itself to an aesthetic of traumatic remembering based on incoherencies, fissures, and incompleteness. Araki's film thus moves a decisive step from the stasis of traumatization and victimization towards what Tom O'Connor calls "the human imagination's capacity for self-creation and rewriting (autopoesis), with the fantastic as a necessary step towards healing in such an open-ended paradigm" (66). Many films about sexualized violence against queers offer no way out, Boys Don't Cry being a prime example here. Some films end in ambiguity such as Cruising and Hedwig and the Angry Inch with protagonists being inflicted by the experience of violence, and whereas they are shown to survive, their fate remains dubious or unknown. More daring films end on a positive note without downplaying the traumatized experience. While we do not know exactly what happens to Sebastian of The Skinny or Joe of Vacationland, the spectator is ascertained that these young men have a future ahead of them even though being marred as victims of abuse and rape. Like these two films but moving a step further, the finale of Mysterious Skin is surprising in the manner it gives way to a reparative impulse. In "learning how to build small worlds of sustenance that cultivate a different present and future for the losses that one has suffered," as Robyn Wiegman explains, "it is about loving what hurts but instead of using that knowledge to prepare for a vigilant stand against repetition, it responds to the future with affirmative richness" (11). Leaving no doubt about the fragmentation, alienation and pain the boys suffered through the horrifying sexual abuse in their childhoods, the audience is not granted with a final-and fake-sense of healing but with open gestures of speechless transcendence. As different as the boys and their experience of sexual violence has been, the wounds they share may never heal, but through the ending's radical act of transformation there is a possibility of tender closeness, a flicker of reparative hope for a future that may allow for other forms of relationships, love, partnership and sexuality. Mysterious Skin has raised the bar of representing sexualized violence against queers in American film, and there continues to be dire need for more public awareness and academic research on this and many more films featuring narratives revolving around injustices against LGBTIQ* characters.

\section{BIBLIOGRAPHY}

Aaron, Michele, Ed. New Queer Cinema: A Critical Reader. New Brunswick: Rutgers UP, 2004.

Aaron, Michele. “The New Queer Spectator.” New Queer Cinema: A Critical Reader. Ed. Michele Aaron. New Brunswick: Rutgers UP, 2004, 187-200.

Abdullah-Khan, Noreen. Male Rape: The Emergence of a Social and Legal Issue. Basingstoke and New York: Palgrave Macmillan, 2008.

Arroyo, José. “Frisk." Sight and Sound 8.1 (1998): 40-41.

Asibong, Andrew. "Unrecognizable Bonds: Bleeding Kinship in Pedro Almodóvar and Gregg Araki.” New Cinema: Journal of Contemporary Film 7.3 (2009): 185-195. 
Basic Instinct. Dir. Paul Verhoeven. Perf. Michael Douglas, Sharon Stone, George Dzundza. TriStar Pictures, 1992.

Benshoff, Harry M., and Sean Griffin. Queer Images: A History of Gay and Lesbian Film in America. Lanham et al.: Rowman \& Littlefield, 2006.

Benshoff, Harry. "The Monster and the Homosexual." Queer Cinema: The Film Reader. Ed. Harry Benshoff and Sean Griffin. New York and London: Routledge, 2004, 63-74.

Bersani, Leo. “Is the Rectum a Grave?" October 43 (1987): 197-222.

Bourke, Joanna. Rape: A History from 1860 to the Present. London: Virago, 2008.

Boys Don't Cry. Dir. Kimberley Peirce. Perf. Hilary Swank, Chloë Sevigny, Peter Sarsgaard. Fox Searchlight, 1999.

Copeland, Kameron J. “The Construction of Racial Identity among Same Gender Loving Black Male Characters in Contemporary Film and Television." Journal of Black Sexuality and Relationships 2.2 (2015): 39-66.

Coulthard, Lisa. "Uncanny Horrors: Male Rape in Bruno Dumont's Twentynine Palms." Rape in Art Cinema. Ed. Dominique Russell. New York and London: Continuum, 2010, 171-184.

Cruising. Dir. William Friedkin. Perf. Al Pacino, Paul Sorvino, Karen Allen. United Artists, 1980.

Davidson, Guy. "Contagious Relations: Simulation, Paranoia, and the Postmodern Condition in William Friedkin's Cruising and Felice Picano's The Lure." GLQ: A Journal of Lesbian and Gay Studies 11.1 (2005): 23-64.

Davies, Jude and Carol R. Smith. "Putting the Homo into America: Reconstructing Gay Identities in the National Frame." Gender, Ethnicity and Sexuality in Contemporary American Film. Edinburgh: Keele UP, 1997, 103-145.

Davies, Michelle and Jenefer Hudson. "Judgments Toward Male and Transgendered Victims in a Depicted Stranger Rape.” Journal of Homosexuality 58 (2011): 237-247.

Davies, Michelle, Jennifer Gilston, and Paul Rogers. "Examining the Relationship between Male Rape Myth Acceptance, Female Rape Myth Acceptance, Victim Blame, Homophobia, Gender Roles, and Ambivalent Sexism." Journal of Interpersonal Violence 27.14 (2012): 2807-2823.

Deliverance. Dir. John Boorman. Perf. Jon Voight, Burt Reynolds, Ned Beatty. Warner Bros., 1972.

Eigenberg, Helen and Agnes Baro. "If You Drop the Soap in the Shower You Are on Your Own: Images of Male Rape in Selected Prison Movies.“ Sexuality \& Culture 7.4 (2003): 56-89.

Eileraas, Karina. "The Brandon Teena Story: Rethinking the Body, Gender Identity, and Violence Against Women." Michigan Feminist Studies 16 (2006). Web. <hdl.handle.net> Date of access: 16 Nov. 2017.

Frisk. Dir. Todd Verow. Perf. Michael Gunther, Craig Chester, Michael Stock. Strand Releasing, 1995.

Gieni, Justine. "Queering Masculinity: Sexual Dissidence as Anti-Bullying Discourse in Kimberly Peirce's Boys Don't Cry." MP: An Online Feminist Journal 3.5 (2012): 1-22. Web. Date of access: 29 Jan 2017.

Graham, Ruth. "Male Rape and the Careful Construction of the Male Victim." Social \& Legal Studies 15. 2 (2006): 187-208.

Halberstam, Judith. “The Transgender Gaze in Boys Don't Cry.” Screen 42.3 (2001): 294-298. 
Hanson, Ellis. “The Languorous Critic.” New Literary History 43.3 (2012): 547-564.

Hawkins, Joan. "Dark, Disturbing, Intelligent, Provocative and Quirky: Avant-Garde Cinema of the 1980s and 1990s." Contemporary American Independent Film: From the Margins to the Mainstream. Ed. Chris Holmlund and Justin Wyatt. London and New York: Routledge, 2005, 89-106.

Hedwig and the Angry Inch. Dir. John Cameron Mitchell. Perf. John Cameron Mitchell, Miriam Shor, Stephen Trask. Killer Films, 2001.

Higgins, Lynn A. "Screen/Memory: Rape and its Alibis in Last Year at Marienbad." Rape and Representation. Ed. Lynn A. Higgins and Brenda R. Silver. New York: Columbia UP, 1991, 303-321.

Holmlund, Chris. “Cruisin' for a Bruisin'. Hollywood's Deadly (Lesbian) Dolls.” Cinema Journal 34.1 (1994): 31-51.

Interior. Leather Bar. Dir. James Franco, Travis Mathews. Perf. Val Lauren, Christian Patrick, James Franco. Strand Releasing, 2013.

Johnny Holiday. Dir. Willis Goldbeck. Perf. William Bendix, Stanley Clements, Hoagy Carmichael. United Artists, 1949.

Kehrwald, Kevin. Prison Movies: Cinema Behind Bars. New York: Wallflower/Columbia UP, 2017.

King Cobra. Dir. Justin Kelly. Perf. Garrett Clayton, Christian Slater, Molly Ringwald. RabbitBandini Productions, 2016.

Klemm, Michael D. “Bangor Buddies.” cinemaqueer.com (Dec 2008). Web. Date of access 16 Nov. 2017.

Koch, Angela. Ir/Reversible Bilder: Zur Visualisierung und Medialisierung von sexueller Gewalt: Berlin: Vorwerk 8, 2015.

Krug, Etienne G. et al. World Report on Violence and Health. Geneva: World Health Organization, 2002.

Lemelle, Anthony. Black Masculinity and Sexual Politics. New York: Routledge, 2010.

McLean, Iain A. “The Male Victim of Sexual Assault." Best Practice \& Research Clinical Obstetrics and Gynaecology 27 (2013): 39-46.

Moddelmog, Debra A. "Can Romantic Comedy Be Gay? Hollywood Romance, Citizenship, and Same-Sex Marriage Panic.” Journal of Popular Film and Television 36.4 (2009): 162-172.

Montgomery, Kathryn. “Gay Activists and the Networks." Journal of Communication 31.3 (1981): 49-57.

Morris, Gary. “William Friedkin's Cruising.” Bright Lights Film Journal 16 (April 1996). Web. <brightlightsfilm.com> Date of access 27 Dec. 2017.

Muñoz, José Esteban. Disidentifications: Queers of Color and the Performance of Politics. Minneapolis: U of Minnesota P, 1999.

Mysterious Skin. Dir. Gregg Araki. Perf. Brady Corbet, Joseph Gordon-Levitt, Elisabeth Shue. Antidote Films/Desperate Pictures, 2004.

O'Connor, Tom. "Trauma and Becoming-Art in Gregg Araki's Mysterious Skin and Asia Argento's The Heart is Deceitful Above All Things." Journal of the Fantastic in the Arts 21.1 (2010): 54-76.

Paul, William. Laughing Screaming: Modern Hollywood Horror and Comedy. New York: Columbia UP, 1994.

Phillips, John. Transgender on Screen. Basingstoke and New York: Palgrave Macmillan, 2006. 
Poole, Ralph J. “Towards a Queer Futurity: New Trans Television.” European Journal of American Studies 12.2 (2017). Web. <ejas.revues.org> Date of access 14. Nov. 2017.

Pulp Fiction. Dir. Quentin Tarantino. Perf. John Travolta, Uma Thurman, Samuel L. Jackson. Miramax, 1994.

Vacationland. Dir. Todd Verow. Perf. Brad Hallowell, Gregory J. Lucas. Bangor Films, 2006.

Rich, B. Ruby. New Queer Cinema: The Director's Cut. Durham and London: Duke UP, 2013.

Russo, Vito. The Celluloid Closet: Homosexuality in the Movies. Rev. Ed. New York et al.: Harper and Row, 1987.

Scarce, Michael. Male on Male Rape: The Hidden Toll of Stigma and Shame. Cambridge: Perseus, 1997.

Scott, Darieck. Extravagant Abjection: Blackness, Power, and Sexuality in the African American Literary Imagination. London and New York: New York UP, 2010.

Sedgwick, Eve Kosofsky. "Paranoid Reading and Reparative Reading; or, You're So Paranoid, You Probably Think This Introduction Is About You." Novel Gazing: Queer Readings in Fiction. Ed. Eve Kosofsky Sedgwick. Durham: Duke UP, 1997, 1-33.

Sherwin, Miranda. "Deconstructing the Male: Masochism, Female Spectatorship, and the Femme Fatale in Fatal Attraction, Body of Evidence, and Basic Instinct." Journal of Popular Film and Television 35.4 (2008): 174-182.

Sielke, Sabine. Reading Rape: The Rhetoric of Sexual Violence in American Literature and Culture, 1790-1990. Princeton and Oxford: Princeton UP, 2002.

Stephan, Inge. "Im toten Winkel: Die Neuentdeckung des 'ersten Geschlechts' durch men's studies und Männlichkeitsforschung." Männlichkeit als Maskerade: Kulturelle Inszenierungen vom Mittelalter bis zur Gegenwart. Ed. Claudia Benthien and Inge Stephan. Köln et al.: Böhlau, 2003, 11-35.

Stockton, Kathryn Bond. Beautiful Bottom, Beautiful Shame: Where "Black" Meets "Queer." Durham and London: Duke UP, 2006.

Stoltenberg, John. "Pornography and Freedom." Making Violence Sexy: Feminist Views on Pornography. Ed. Diana E. H. Russell. New York: Teachers College Press, 1993, 65-77.

Stott, Andrew. Comedy. New York and London: Routledge, 2005.

Strongman, Roberto. "Sizing up the Queer Black Thug Lover: The Down Low as Counter Discourse to Homonormativity." Screening Noir, Journal of Black Film, Television \& New Media Culture 1.2 (2008): $17-29$.

Swoon. Dir. Tom Kalin. Perf. Daniel Schlachet, Craig Chester, Ron Vawter. American Playhouse/ Killer Films, 1992.

Taubin, Amy. "Beyond the Sons of Scorsese." Sight and Sound 2.5 (1992): 37.

The Skinny. Dir. Patrick-Ian Polk. Perf. Jussie Smollett, Blake Young-Fountain, Anthony Burrell. Tall Skinny Black Boy Productions, 2012.

Verow, Todd. "No More Mr. Nice Gay: A Manifesto (USA, 2009)." Film Manifestos and Global Cinema Cultures: A Critical Anthology. Ed. Scott MacKenzie. Berkeley et al.: U of California P, 2014, 392-395.

Watney, Simon. “Hollywood's Homosexual World.” Screen 23.3-4 (1982): 107-21.

"What is BMX?" bmxnational.org. Web. Date of access 16 Nov. 2017.

"What Is Sexual Violence? Fact Sheet." 2010. National Sexual Violence Resource Center. Web. $<$ nsvrc.org> Date of access 28 Dec. 2017. 
Weiss, Andrea. Vampires and Violets: Lesbians in the Cinema. London: Jonathan Cape, 1992.

Wiegman, Robyn. “The Times We're In: Queer Feminist Criticism and the Reparative 'Turn.” Feminist Theory 15.1 (2014): 4-25.

Williams, Linda. "Blood Brothers." Sight and Sound 4.8 (1994): 16-19.

Wilson, Alexander. “Friedkin's Cruising, Ghetto Politics, and Gay Sexuality.” Social Text 4 (1981): 98-109.

Wlodarz, Joe. "Rape Fantasies: Hollywood and Homophobia." Masculinity: Bodies, Movies, Culture. Ed. Peter Lehman. New York and London: Routledge, 2001, 67-80.

\section{NOTES}

1. I am not getting into a discussion of this film for various reasons. The film, for example, has been one of the rare examples being discussed in studies which otherwise predominantly address sexualized violence against women (e.g. Sielke; Koch), and although strictly speaking, none of the men of Deliverance are gay, Sielke nevertheless advises us to read the film's "homoerotically charged fantasies of rape and castration as a regression into a precivilized, primitive condition" (177). Intriguingly, many reviews of the film "miss" the rape scene, a "mis-remembering," as Linda Williams warns, that critics and audiences share. If both groups are "desperate to bury and forget, this is perhaps because those in the film are too" (19). A more recent provoking example of a film that includes male rape within the context of sexual violence in the art house film is Twentynine Palms (Bruno Dumont, 2003). See Coulthard; Koch (190-203).

2. Among the discussed films are The Prince of Tides (Barbra Streisand, 1991), Pulp Fiction (Quentin Tarantino, 1994), The Shawshank Redemption (Frank Darabont, 1994), Sleepers (Barry Levinson, 1996), Your Friends and Neighbors (Neil LaBute, 1998), American History X (Tony Kaye, 1998).

3. Later films set in prison or prison-like locations similarly suggest or even openly-if rarelydepict rape scenes, from Fortune and Men's Eyes (Harvey Hart and Jules Schwerin, 1971) to Edmond (Stuart Gordon, 2005) (see Eigenberg and Baro; Kehrwald 68-98; Bourke 329-356). Other films set in institutional contexts such as Baseball Diaries (Scott Kalvert, 1995) and Doubt (John Patrick Shanley, 2008) show traumatized male adults who have been sexually (and emotionally) abused in their childhood (or in the case of Doubt a boy suspected of being molested by a Catholic priest).

4. For another film featuring a highly problematic lesbian serial killer see Monster (Patty Jenkins, 2003), based on the case of Aileen Wuornos.

5. While the vampire genre lends itself more easily towards queer pleasure, the transvestite/ transsexual killer film does less so (at least for the writer of this article), if we take films such Myra Breckinridge (Michael Sarne, 1970), Dressed to Kill (Brian De Palma, 1980), and Silence of the Lambs (Jonathan Demme, 1991) as representable examples (see Phillips 85-114).

6. For examples of such transgender romances partially undermining the heteronormative gaze see my discussion of the television mini-series Hit \& Miss (2012, dir. Paul Abbott), which includes scenes of sexualized violence against a transwoman.

7. As a reaction to such stereotypical misconceptions, the term "same gender loving" was coined for black homosexual and bisexual men as "an Afro-centric alternative to what are deemed Eurocentric homosexual identities (e.g., gay and lesbian) which do not culturally affirm or engage the history and cultures of people of African descent" ("What is BMX?"). 


\section{ABSTRACTS}

This essay discusses ways both mainstream Hollywood films and independent cinema have addressed sexualized violence against queers. I am looking at a number of significant films that refrain from stereotypically correlating queerness, sexuality, and violence, opting for a critical assessment of this conflation and offering alternative viewpoints, instead. First highlighting the controversies around prominent films such as Cruising and Boys Don't Cry, I then look at lesser known, but noteworthy examples (e.g. Hedwig and the Angry Inch, The Skinny, Vacationland, and Mysterious Skin), films arising out the independent film movement known as New Queer Cinema. Focusing on the generic conventions, the narrative strategies and aesthetic means of these films, I probe into the ways they aim to affectively engage the audience and discuss their respective cinematic approaches of envisioning justice for people from the LGBTIQ* community who have experienced violence in sexualized contexts.

\section{INDEX}

Keywords: sexual violence against queers; child abuse; male-on-male rape; queer theory; New Queer Cinema; queers of color; transgender characters in film

\section{AUTHOR}

\section{RALPH J. POOLE}

Ralph J. Poole is an American-German researcher who teaches as Professor of American Studies at the University of Salzburg, Austria. He taught at the University of Munich, Germany, at Fatih University in Istanbul, Turkey, and was a research scholar at CUNY's Center for Advanced Studies in Theater Arts in Manhattan, at Concordia University, Irvine, at the University of Minnesota, Minneapolis, at the Center Austria in New Orleans, at the University of the West Indies in Kingston, Jamaica, at Uniwersytet Jagielloński in Kraków, Poland, and at the Venice International University in Venice, Italy. Amongst his publications is a book-length study on the Avant-Garde tradition in American theatre, a book on satirical and autoethnographical cannibal texts and an essay collection on dangerous masculinities. His main research interests are gender and queer studies, popular culture, and transnational American Studies. 